\section{Effectiveness of Denture Cleanser Associated With Microwave Disinfection and Brushing of Complete Dentures: In Vivo Study}

Newton Sesma ${ }^{1}$, Alessandra Lima Rocha ${ }^{1}$, Dalva Cruz Laganá ${ }^{1}$ Bruno Costa ${ }^{1}$, Susana Morimoto ${ }^{2}$
'Department of Prosthodontics, School of Dentistry, USP - University of São Paulo, São Paulo, SP, Brazil ${ }^{2} S$ chool of Dentistry, UNIB - Ibirapuera University, São Paulo, SP, Brazil

Correspondence: Prof. Dr. Newton Sesma, Avenida Prof. Lineu Prestes, 2227, 05508-000 São Paulo, SP, Brasil. Tel/Fax: +55-11-30917888. e-mail: sesma@usp.br
Complete dentures acts as a reservoir for microbial colonization, which may lead to systemic infections. Microwave irradiation has been used as an efficient method of denture disinfection. Even though current methods eliminate denture-base microorganisms, a recurrence rate of denture stomatitis (DS) is still observed among denture-wearing patients. It was hypothesized that microwave disinfection kills microorganisms but do not remove dead bacteria from the denture surface. To test this hypothesis, the biofilm found in the dentures of 10 patients with DS was evaluated. In addition, the effects of microwave irradiation plus brushing $(\mathrm{MW}+\mathrm{B})$ on the denture biofilm and the combination of denture cleanser with microwave irradiation and brushing $(\mathrm{MW}+\mathrm{DC}+\mathrm{B})$ for the removal of denture-accumulating microorganisms were investigated. Microbiological data were analyzed statistically by nonparametric analysis (Friedman/Wilcoxon, $\alpha=0.05$ ). MW+B and $M W+D C+B$ were effective in reducing the rate of microorganisms $(99.2 \%$ and $99.5 \%$ respectively), but without significant difference between them $(p=0.553)$. However, it was observed that the complete removal of microorganisms from denture surface was only possible when all regimens were combined $(\mathrm{MW}+\mathrm{DC}+\mathrm{B})$. Microwave irradiation in combination with soaking in denture cleanser and brushing effectively disinfected the dentures and removed denture biofilm.
Key Words: denture, microwave, disinfection, denture cleanser, denture stomatitis.

\section{Introduction}

The oral cavity is colonized by various pathogens that may affect the course of a number of systemic diseases including aspiration pneumonia (1), gastrointestinal infection and chronic obstructive pulmonary disease (2). It is known that complete and removable dentures accumulate microorganisms, particularly Candida albicans, on the porous surface of the acrylic resin (3). This microbial colonization is one of the main etiological factors associated with denture stomatitis $(3,4)$.

In its latest guideline for care and maintenance of complete dentures, the American College of Prosthodontists (5) states that regular brushing of the denture with toothpaste reduces the biofilm mass but has no impact on Candida $s p$ colonization (6). Patients with limited manual dexterity and/or visual impairments require auxiliary chemical methods for cleaning of dentures. Hypochlorite solutions are highly effective but potentially damaging to prostheses (5). Denture cleansers are generally harmless effervescent tablets that also reduce the biofilm mass found in dentures, nevertheless, neither chemical methods nor brushing, used separately, can be considered as an efficient antiseptic-germicide solution $(7,8)$.

In addition to the methods used for denture cleansing, microwave irradiating the dentures has also been used as an inexpensive alternative for denture disinfection (9-11), and is efficient in eliminating denture-base microorganisms (12-14). However, a recurrence rate of denture stomatitis is still observed among denture-wearing patients, especially when antifungal therapy is discontinued $(4,10)$. According to a recent review on this subject, epidemiological studies show a prevalence of between $15 \%$ and $70 \%$ for the occurrence of stomatitis among denture wearers (4).

The objective of this study was to analyze the effect of the microwave irradiation in combination or not with a chemical denture cleanser on the removal of dentureaccumulating microorganisms, using microbiological analysis and scanning electron microscopy (SEM). The tested hypothesis was that microwave disinfection kills the microorganisms but does not remove dead bacteria from denture surface.

\section{Material and Methods}

The participants of this study were ten 50-60-year-old male patients with completely edentulous maxilla and mandible with clinical signs of Newton's type II denture stomatitis (15) and dentures with no more than 10 years of use. Patients under treatment with antibiotics and/ or antifungals were not included. All patients signed an informed consent form and the institutional Ethics 
Committee approved the clinical protocol (Process \# 107/01). The maxillary dentures were subjected to two disinfection methods, each used for 7 days in a random sequence. A 30day washout period between the methods was respected, during which the patient performed only brushing with dentifrice to clean the dentures. Method 1: microwave irradiation + brushing $(\mathrm{MW}+\mathrm{B})$. Patients were instructed to brush their dentures after meals with a soft-bristle toothbrush (Oral B, Laboratórios Oral B, São Paulo, SP, Brazil) and dentifrice (Colgate Total 12; Colgate/Palmolive, São Paulo, SP, Brazil) and a once a day to put them in a microwave steam sterilizer (Baby Bottle Microwave Steam Sterilizer; Kuka, São Paulo, SP, Brazil) with $500 \mathrm{~mL}$ of water and irradiate them in the microwave oven for $3 \mathrm{~min}$ at 700 W (16). Method 2: microwave irradiation + denture cleanser + brushing $(\mathrm{MW}+\mathrm{DC}+\mathrm{B})$. Patients proceeded to microwave irradiation followed by soaking for $8 \mathrm{~h}$ in a new denture enzymatic cleanser dissolved in $100 \mathrm{~mL}$ of warm water (Ortoform; Farmácia de Manipulação Fórmula e Ação, São Paulo, SP, Brazil), and were then instructed to brush their dentures as described previously.

Two triangular pieces of approximately $3 \mathrm{~mm}$ from the internal surface at the posterior region of the upper denture analysis while the other was processed for SEM analysis.

\section{Microbiological Analysis}

One of the fragments removed from the prosthesis of each patient was placed in a tube containing $2.5 \mathrm{~mL}$ of transport medium VMGA III (viability medium, Göteborg, anaerobically prepared III). All tubes were sent at room temperature to the laboratory for microbiological analysis and were handled within $4 \mathrm{~h}$ of sample collection. The tubes containing semisolid transport medium were incubated for $15 \mathrm{~min}$ in an oven at $37^{\circ} \mathrm{C}$ for liquefaction of gelatin. These tubes were agitated in the Vortex for $60 \mathrm{~s}$ and diluted in peptone water. Aliquots of each dilution were inoculated on Brucella agar plus 5\% defibrinated sheep blood, hemin and menadione, and the plates were incubated for 10 days in microaerophilic atmosphere $\left(10 \% \mathrm{CO}_{2}\right)$. Aliquots were also inoculated on the surface of Sabouraud agar. After incubation, plates containing 30-300 colonies were selected. Colonies present in blood agar plates were counted to determine the total number of viable bacteria per sample and in the Sabouraud agar plates to determine the presence of yeasts.

Table 1. Total count of viable bacteria and reduction rate after treatments

\begin{tabular}{|c|c|c|c|c|c|}
\hline $\begin{array}{l}\text { Treatment } \\
\text { methods }\end{array}$ & $\begin{array}{l}\text { Moment } \\
\text { of analysis }\end{array}$ & 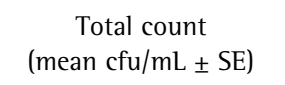 & $\begin{array}{c}\mathrm{p} \\
\text { value }\end{array}$ & $\begin{array}{l}\text { Reduction rate } \\
(\text { mean } \pm \mathrm{SE}-\%)\end{array}$ & $\begin{array}{c}\mathrm{p} \\
\text { value }\end{array}$ \\
\hline \multirow{2}{*}{$\mathrm{MW}+\mathrm{B}$} & Before & $2.3 \times 10^{7} \pm 3.09 \times 10^{6}$ & \multirow{2}{*}{$0.005^{*}$} & \multirow{3}{*}{$\begin{array}{c}0.008 \pm 0.004 \\
(99.2)\end{array}$} & \\
\hline & After & $2.17 \times 10^{5} \pm 9.37 \times 10^{4}$ & & & \\
\hline & & & & & 0.271 \\
\hline \multirow{3}{*}{$\mathrm{MW}+\mathrm{DC}+\mathrm{B}$} & Before & $2.1 \times 10^{7} \pm 3.6 \times 10^{6}$ & \multirow{3}{*}{$0.005^{*}$} & \multirow{3}{*}{$\begin{array}{c}0.005 \pm 0.002 \\
(99.5)\end{array}$} & \\
\hline & & & & & \\
\hline & After & $1.05 \times 10^{5} \pm 4.69 \times 10^{4}$ & & & \\
\hline
\end{tabular}

$\mathrm{SE}=$ standard error. *Significant at 5\%.

\section{SEM Analysis}

The second fragment of the prosthesis was placed in a tube containing the fixative solution of $2 \%$ glutaraldehyde in phosphate buffer and kept in refrigerator at $4{ }^{\circ} \mathrm{C}$ for $48 \mathrm{~h}$. They were then washed in sucrose phosphate and dehydrated by a series of alcohols of increasing concentration. The drying process was completed in continuous flow of carbon dioxide. The completely dry material was glued to aluminum bases and subjected to plating with gold layer 15 to $20 \mathrm{~nm}$. The samples were examined before and after $\mathrm{MW}+\mathrm{B}$ and $\mathrm{MW}+\mathrm{DC}+\mathrm{B}$ in a scanning electron microscope (LEO 430; Zeiss Leica, England).

\section{Statistical Analysis}

To investigate whether significant differences between microbial counts and reduction rate of microorganisms according to treatment could be detected, the values were submitted to nonparametric analysis using the Friedman and Wilcoxon tests. The significance level was set at 5\%.

\section{Results}

Quantitative Microbiological Analysis

$\mathrm{MW}+\mathrm{B}$ and $\mathrm{MW}+\mathrm{DC}+\mathrm{B}$ were both very effective treatments in disinfecting the dentures, reducing by $99.2 \%$ and $99.5 \%$ on average, the number of bacteria, respectively. There was no significant difference between the two regimens in relation to total bacteria counts $(p=0.271)$. Also, the difference between the reduction rates of both methods was not significantly different $(p=0.553)$ (Table 1). The mean colony-forming units per millimeter (cfu/mL) for yeasts was $2.6 \times 10^{7} \pm 7.2 \times 10^{3}$ before $\mathrm{MW}+\mathrm{B}$, and $2.3 \times 10^{7} \pm 5.42 \times 10^{3}$ before $\mathrm{MW}+\mathrm{DC}+\mathrm{B}$. No yeasts were present after the treatment protocols.

\section{Results of Qualitative SEM Analysis}

Figure 1 shows a dense biofilm covering the entire denture surface before MW+B. SEM micrographs of the 
dentures after microwave irradiation (Fig. 2A) revealed the presence of microorganisms, even though the microorganism count was virtually zero. Figure $2 B$ shows, at higher magnification, an altered bacteria morphology

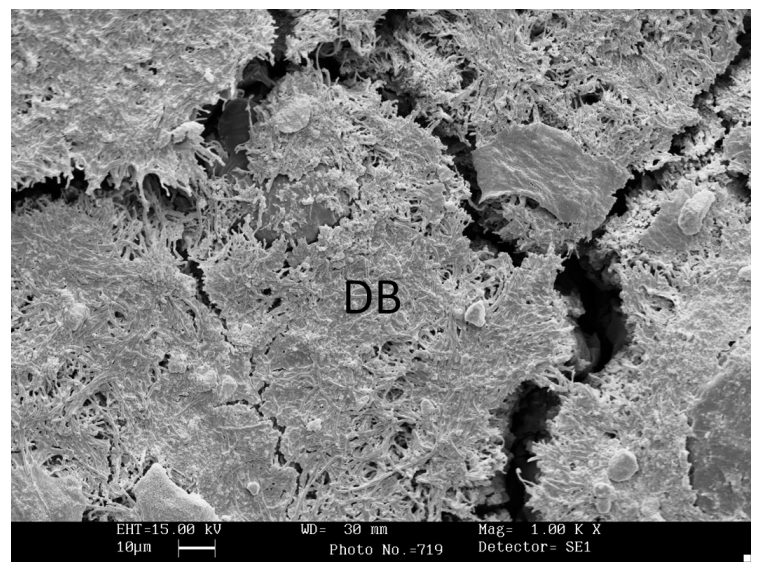

Figure 1. Before MW+B (SEM 1,000x). Dense biofilm covering the entire denture surface. $\mathrm{DB}=$ denture biofilm. and cell walls damaged after microwaving, preventing their growth in culture. The combination of microwave and denture cleanser not only decreased the number of microorganisms on denture surface, but also removed the biofilm of dead microorganisms (Figs. 3 and 4, before and after treatment, respectively).

\section{Discussion}

To test the hypothesis that microwave disinfection kills the microorganisms but does not remove dead bacteria from the denture surface, microbiological SEM analyses of the dentures were undertaken after microwave irradiation. The SEM micrographs revealed the presence of microorganisms when microwave and brushing were used. In contrast, when microwave, brushing and denture cleanser were combined, the biofilm was successfully removed. The SEM images after microwaving also revealed morphological changes in bacteria similar to those observed by Rosaspina et al. (17), who showed that the microwave bactericidal action disrupts the cell wall of bacteria and fungi, but fails to remove non-
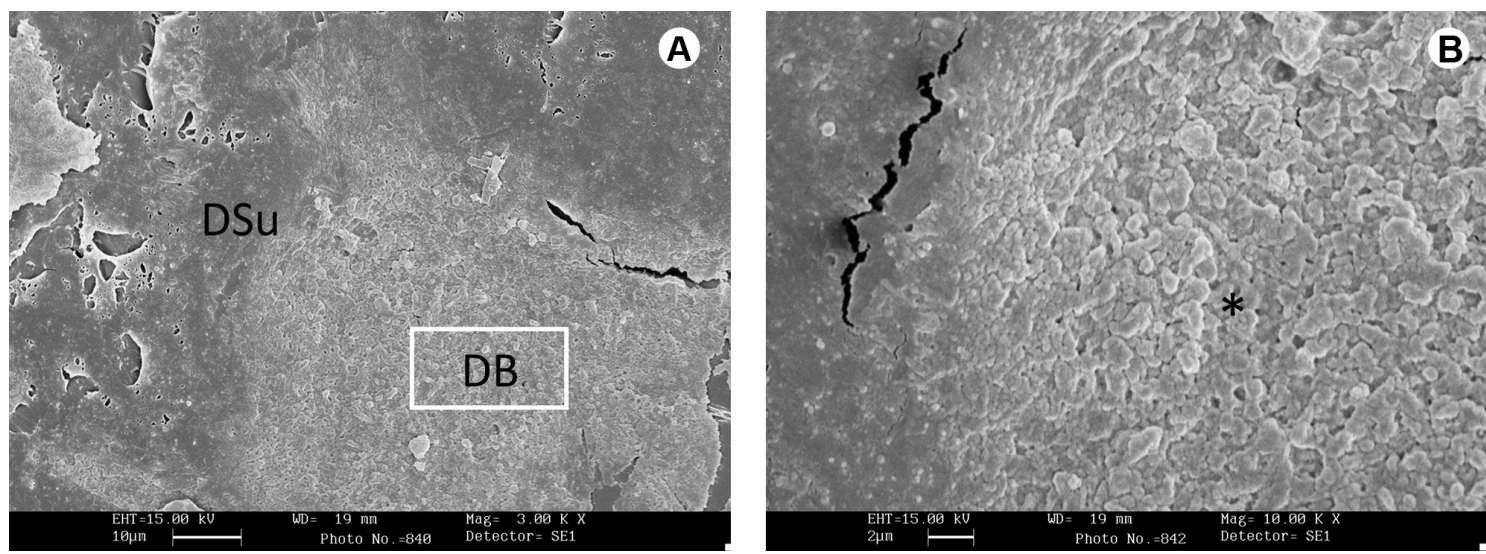

Figure 2. After MW+B (SEM 3,000x). A: Presence of biofilm probably formed by non-viable microorganisms. DB=denture biofilm; DSu=denture surface. Magnification of "A" (SEM 10,000x) showing morphological changes in the dead bacteria (*).

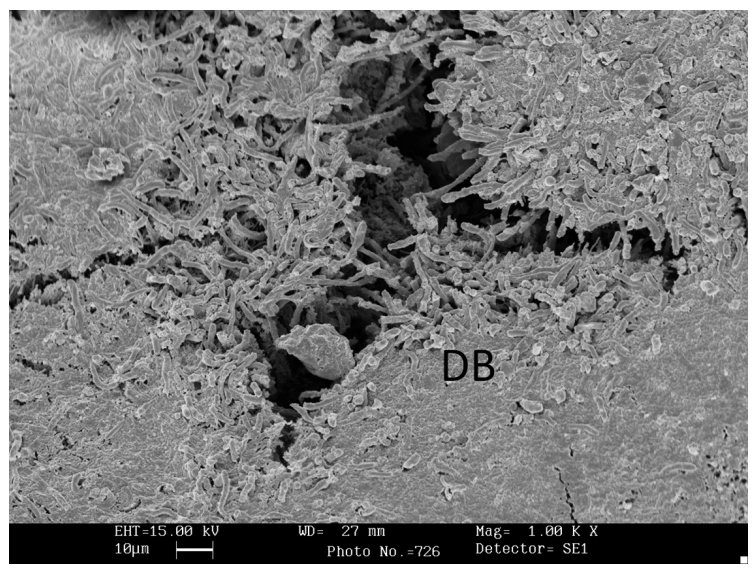

Figure 3. Before MW+DC+B (SEM 1.000x). Presence of thick biofilm on the denture. $\mathrm{DB}=$ denture biofilm.

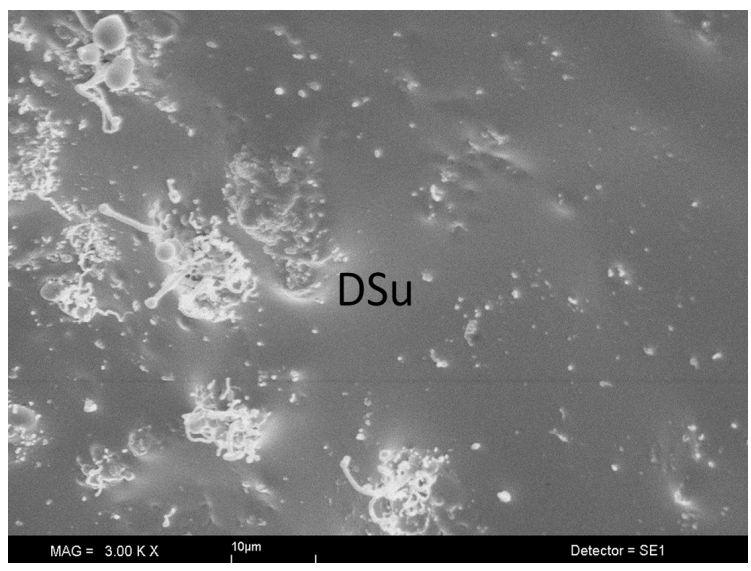

Figure 4. After MW +DC+B (SEM 3.000x). Inner surface of the denture virtually free of biofilm. DSu=denture surface. 
viable microorganisms from the denture surface.

Indeed, the classic experiments performed back in 1944 (18) showed that DNA molecules still present in dead bacteria might be transferred to live bacteria. Thus, the live bacterial cell may incorporate new inherited traits from dead bacteria, including drug-resistance genes. In the present study, a biofilm of dead microorganisms still remained on the denture after microwave irradiation and it could be hypothesized that this biofilm may favor bacterial recolonization and contribute to DS recurrence. However, more clinical studies are necessary to prove that this residual matrix and proteins can favor the colonization of surface or it can induce production of a virulence factor in the new biofilm.

Some authors $(9,11,14)$ have suggested denture microwave disinfection in water because bubbles released by boiling water help removing microorganisms from the surface. Others have recommended denture disinfection with steam heat in the microwave oven (16).

In the present study, microwave steam disinfection was preferred because studies have shown that significant changes in internal adaptation, surface roughness (19), hardness (20), and dimensional stability (21)
In the present study, an in vivo approach was applied to investigate denture disinfection efficiency because previous studies done in vitro have failed to fully reproduce the buccal environment of the patient. The in vitro biofilm showed significant differences from the in vivo biofilm with regard to intermicrobial adhesion and the adhesion to the resin surface (22). Additionally, the frequency with which this biofilm is removed and renewed in vivo cannot be simulated in vitro (23).

The denture cleanser used in the present study was an alkaline peroxidase solution recently developed for the Brazilian healthcare market. The proteolytic enzyme, released when dissolved in water, acts by breaking the connections of the intermicrobial matrix of the denture biofilm, which is composed of salivary glycoproteins and bacterial polysaccharides $(5,8)$. The association of physical (microwave) + chemical (effervescent cleanser) + mechanical (brushing) methods has shown bactericidal and fungicidal effects and also removed the dead microorganisms from the denture base, in agreement with the results of Senna et al. (24), who noted that this association also allows disinfecting dentures in a shorter irradiation time and lower temperature.

Banting and Hill (25) and Neppelenbroek et al. (10) reported that microwave denture disinfection eliminated the mycelial forms of Candida from the dentures of patients with denture stomatitis. A follow-up period of 90 days showed no reinfection of the mucosa; however the dentures had a high rate of reinfection. All yeasts were eliminated by microwave irradiation in the present study, but clinical monitoring of signs of denture stomatitis was not performed. Another limitation was that patients with palatal inflammatory papillary hyperplasia (Newton type III denture stomatitis) were not evaluated.

Due to an increased resistance of yeasts to antifungal agents and the toxicity of these drugs, alternative treatments for DS have been proposed $(10,12,13)$. This study did not aim to treat DS, but revealed results that may be useful in future studies for this purpose.

Poor oral health can negatively affect the mental, social, and general systemic health and physical well being of denture wearers $(1,2)$. With longevity increasing, the elderly population keeps growing worldwide and the vast majority of denture-wearing patients are the elderly. The impact of denture hygiene on general and oral health needs further investigation. Additional exploration on effective cleaning methods may improve the quality of denture use and longterm clinical evaluations of different cleaning methods for safety and efficacy should be performed.

The combination of microwave irradiation, denture cleanser and brushing effectively removed the biofilm that remained on the denture after disinfection.

\section{Resumo}

Próteses totais agem como um reservatório para a colonização microbiana, que pode levar a infecções sistêmicas. Irradiação com microondas tem sido usada como um método eficiente de desinfecção das próteses. Apesar dos métodos atuais eliminarem os microorganismos da base protética, uma taxa de recidiva ainda é observada entre pacientes que usam próteses dentárias. Hipotetizamos que a desinfecção com microondas consegue matar os microorganismos, mas não remove as bactérias mortas da superfície da prótese. Para testar essa hipótese, o biofilme encontrado nas próteses de 10 pacientes com estomatite protética foi analisado. Além disso, os efeitos da irradiação por microondas + escovação $(M W+B)$ no biofilme da prótese e a associação de um higienizador de prótese com a irradiação por microondas e escovação $(M W+D C+B)$ para a remoção dos microorganismos da prótese foram investigados. Dados microbiológicos foram avaliados por análise não paramétrica (Friedman/Wilcoxon, $\alpha=0,05$ ). $\mathrm{MW}+\mathrm{B}$ e $\mathrm{MW}+\mathrm{DC}+\mathrm{B}$ foram efetivos em reduzir a taxa de microorganismos $(99,2 \%$ e 99,5\%, respectivamente), mas não houve diferença significativa entre eles $(p=0,553)$. Entretanto, observamos que a completa remoção dos microorganismos só foi possivel quando todos os métodos foram associados (MW+DC+B). Irradiação por microondas associada à imersão em higienizador de prótese e escovação efetivamente desinfetou a prótese e removeu o biofilme da prótese.

\section{References}

1. Sumi $Y$, Miura $H$, Michiwaki $Y$, Nagaosa $S$, Nagaya M. Colonization of dental plaque by respiratory pathogens in dependent elderly. Arch Gerontol Geriatr 2007;44:119-124.

2. Coulthwaite L, Verran J. Potential pathogenic aspects of denture plaque. Br J Biomed Sci 2007;64:180-189. 
3. Cenci TP, Del Bel Cury AA, Crielaard W, Ten Cate JM. Development of Candida-associated denture stomatitis: new insights. J Appl Oral Sci 2008;16:86-94

4. Gendreau L, Loewy ZG. Epidemiology and etiology of denture stomatitis. J Prosthodont 2011;20:251-260.

5. Felton D, Cooper L, Duqum I, Minsley G, Guckes A, Haug S, et al.. Evidence-based guidelines for the care and maintenance of complete dentures: a publication of the American College of Prosthodontists. J Prosthodont 2011;20:S1-S12.

6. Panzeri H, Lara EHG, Paranhos HFO, Silva CHL, Souza RF, Gugelmin MCMS, et al.. In vitro and clinical evaluation of specific dentifrices for complete denture hygiene. Gerodontology 2009;26:26-33.

7. Gornitsky M, Paradisi I, Landaverde G, Malo AM, Velly AM. A clinical and microbiological evaluation of denture cleansers for geriatric patients in long-term care institutions. J Can Dent Assoc 2002;68:39-45.

8. Ferreira MA, Pereira-Cenci T, Rodrigues de Vasconcelos LM, RodriguesGarcia RC, Del Bel Cury AA. Efficacy of denture cleansers on denture liners contaminated with Candida species. Clin Oral Invest 2009;13:237-242.

9. Campanha $\mathrm{NH}$, Pavarina $\mathrm{AC}$, Brunetti IL, Vergani $\mathrm{CE}$, Machado $\mathrm{AL}$, Spolidorio DMP. Candida albicans inactivation and cell membrane integrity damage by microwave irradiation. Mycoses 2007;50:140-147.

10. Neppelenbroek KH, Pavarina AC, Spolidorio EMP, Massucato EM, Spolidorio LC, Vergani CE. Effectiveness of microwave disinfection of complete dentures on the treatment of Candida-related denture stomatitis. J Oral Rehabil 2008;35:836-846.

11. Ribeiro DG, Pavarina AC, Dovigo LN, Spolidorio DM, Giampaolo ET, Vergani CE. Denture disinfection by microwave irradiation: a randomized clinical study. J Dent 2009;37:666-672.

12. Sanitá PV, Machado AL, Pavarina AC, Massucato EM, Colombo AL, Vergani CE. Microwave denture disinfection versus nystatin in treating patients with well-controlled type 2 diabetes and denture stomatitis: a randomized clinical trial. Int J Prosthodont 2012;25:232-244.

13. Silva MM, Mima EG, Colombo AL, Sanitá PV, Jorge JH, Massucato EM, et al.. Comparison of denture microwave disinfection and conventional antifungal therapy in the treatment of denture stomatitis: a randomized clinical study. Oral Surg Oral Med Oral Pathol Oral Radiol 2012;114:469-479.

14. Mima EG, Pavarina AC, Neppelenbroek $K H_{\text {, Vergani }} C E$, Spolidorio
DM, Machado AL. Effect of different exposure times on microwave irradiation on the disinfection of a hard chairside reline resin. $J$ Prosthodont 2008;17:312-317.

15. Newton AV. Denture sore mouth. Br Dent J 1962;112:357-360

16. Sesma N, Gil C, Kolikauskas WA, Silva RA, Pannuti CM. Temperature of denture base resin under different protocols of microwave irradiation. Braz Dent J 2011;22:388-391.

17. Rosaspina $S$, Anzanel A, Salvatorelli G. Microwave sterilization of enterobacteria. Microbios 1993;76:263-270.

18. Avery OT, MacLeod CM, McCarty M. Studies on the chemical nature of the substance inducing transformation of pneumococcal types. J Exp Medicine 1944;79:137-158.

19. Sartori EA, Schmidt CB, Walber LF, Shinkai RSA. Effect of microwave disinfection on denture base adaptation and resin surface roughness. Braz Dent J 2006;17:195-200.

20. Consani RLX, Azevedo DD, Mesquita MF, Mendes WB, Saquy PC. Effect of repeated disinfections by microwave energy on the physical and mechanical properties of denture base acrylic resins. Braz Dent $J$ 2009;20:132-137.

21. Sartori EA, Schmidt CB, Mota EG, Hirakata LM, Shinkai RSA. Cumulative effect of disinfection procedures on microhardness and tridimensional stability of a poly (methyl methacrylate) denture base resin. J Biomed Mater Res Part B Biomater 2008;86:360-364.

22. Radford DR, Challacombe SJ, Walter JD. Adherence of phenotypically switched Candida albicans to denture base materials. Int J Prosthod 1998;11:75-81.

23. Nikawa $H$, Hamada $T$, Yamashiro $H$, Kumagai $H$. A review of in vitro and in vivo methods to evaluate the efficacy of denture cleansers. Int J Prosthodont 1999;12:153-159.

24. Senna PM, Sotto-Maior BS, Silva WJ, Del Bel Cury AA. Adding denture cleanser to microwave disinfection regimen to reduce the irradiation time and the exposure of dentures to high temperatures. Gerodontology 2013;30:26-31.

25. Banting DW, Hill SA. Microwave disinfection of dentures for the treatment of oral candidiasis. Spec Care Dentist 2001;21:4-8.

Received April 9, 2013 Accepted June 14, 2013 